\title{
The Determination of Serum Estradiol, Testosterone and Progesterone in Acute Myocardial Infarction
}

\author{
Seydi Vakkas Aksüt, M.D., Gonul Aksüt, Ph.D.,* \\ Aydin Karamehmetoglu, M.D., and Erdem Oram, M.D.**
}

\section{SUMMARY}

The levels of serum estradiol, testosterone and progesterone were determined in 13 cases of acute myocardial infarction. Thirteen intensive care patients without coronary, hepatic or renal disease, 13 cases of unstable angina and 15 normal subjects. The patients were males ranging from 24 to 56 years of age, the average being 40.4 years. The levels of serum estradiol in the acute myocardial infarction and unstable angina groups were significantly higher than in the normal group, and no difference was found between the normal and intensive care patient. The testosterone levels were significantly lower in the acute myocardial infarction and unstable angina groups than in the normal group. Progesterone levels increased in acute myocardial infarction patients. The estradiol: testosterone ratio was considerably elevated in the acute phase of myocardial infarction, and in unstable angina patients. No difference was found between the intensive care patient and normal groups.

\section{Additional Indexing Words:}

Acute myocardial infarction Unstable angina Estradiol Testosterone Progesterone

\footnotetext{
$\mathrm{V}$ ARIOUS studies have shown that serum levels of estradiol and estrone are high in middle-aged men with acute myocardial infarction. ${ }^{1)-5}$ ) However, serum levels of testosterone, androstenedione and dihydrotestosterone are unaffected by acute myocardial infarction. Thus, it was suggested that hyperestrogenemia could be a risk factor in middle-aged men for myocardial infarction. Studies on men who had been given estrogens have supported the view that estrogen could be a risk factor in men. For example, the incidence

From the Department of Cardiology, Faculty of Medicine, Hacettepe University, Ankara, Turkey.

* Research Fellow in the Department of Nuclear Medicine.

** Professor, Chief of Internal Medicine.

Address for reprint: S. V. Aksüt, M.D., Hacettepe University, Faculty of Medicine, Department of Cardiology, Ankara, Turkey.

Received for publication July 12, 1985.

Manuscript revised February 19, 1986.
} 
of reinfarction is higher in patients given estrogens than in age-matched patients who did not receive estrogen therapy, and the rate of re-infarction has a positive correlation with the estrogen dose.6),9) Furthermore, the mortality rate in cardiovascular disease increased in cases where estrogen was given for the treatment of prostate carcinoma. ${ }^{8)}$ By contrast, the relation between estrogens and myocardial infarction in women is more complex. The incidence of myocardial infarction in premenopausal women is significantly lower than in men of the same age group. ${ }^{9}$

Both bilateral oophorectomy and early menopause are associated with an increased risk of premature ischemic heart discasc. ${ }^{10)-12)}$

These findings suggest that women may be protected against myocardial infarction by estrogen. However, the risk of myocardial infarction is increased in young women using oral contraceptives which contain estrogen, ${ }^{13), 14}$ and estrogen may interact with other risk factors. ${ }^{15)}$ Therefore, the relation between estrogen and myocardial infarction may differ with age in men and women.

The serum levels of testosterone in the acute phase of myocardial infarction have not been investigated. Although serum testosterone levels in coronary heart disease have been studied by several investigators, the results are contradictory. While some studies have reported either little or no

Table I. Serum Estradiol, Testosterone and Progesterone

\begin{tabular}{|c|c|c|c|c|c|c|}
\hline \multirow{2}{*}{$\begin{array}{l}\text { Patient } \\
\text { Number }\end{array}$} & \multirow{2}{*}{$\begin{array}{l}\text { Medi- } \\
\text { cation }\end{array}$} & \multicolumn{3}{|c|}{ Estradiol $(\mathrm{pg} / \mathrm{ml})$} & \multirow{2}{*}{ Mean } & \multirow[b]{2}{*}{ Day 1} \\
\hline & & Day 1 & Day 2 & Day 3 & & \\
\hline 1 & nife & 36 & 42 & 40 & 39.33 & 2.3 \\
\hline 2 & nitr & 48 & 20 & 25 & 31.0 & 2.0 \\
\hline 3 & prop & 32 & 72 & 12.0 & 38.66 & 5.3 \\
\hline 4 & prop & 45 & 24 & 5.0 & 24.66 & 4.8 \\
\hline 5 & nitr & 23 & 120 & 21.5 & 54.83 & 3.4 \\
\hline 6 & nitr & 87 & 50 & 70 & 69.0 & 4.0 \\
\hline 7 & nitr & 310 & 105 & 275 & $230^{*}$ & 4.7 \\
\hline 8 & prop & 120 & 33 & 18 & 57 & 6.9 \\
\hline 9 & prop & 60 & 50 & 24 & 44.66 & 6.0 \\
\hline 10 & morph & 32 & 18 & 95 & 48.33 & 5.8 \\
\hline 11 & lido & 44 & 115 & 67 & 75.33 & 4.6 \\
\hline 12 & nitr & 54 & 55 & 40 & 49.67 & 2.9 \\
\hline 13 & nife & 39 & 27.5 & 80 & 48.83 & 2.2 \\
\hline Mean & & 71.5 & 56.3 & 74.3 & 48.44 & 4.2 \\
\hline SD & & 76.2 & 36.0 & 68.56 & 14.53 & 1.57 \\
\hline
\end{tabular}

prop $=$ propranolol $;$ nife $=$ nifedipine $; \operatorname{morph}=$ morphine $;$ nitr $=$ isosorbide dinitrate $;$ lido $=$ lidocaine. 
difference between patients with coronary heart diseases and normal subjects, ${ }^{3)-5), 16)-181}$ another study has reported that serum testosterone levels are lower in men who have had a myocardial infarction. ${ }^{19)}$ The aim of this study is to determine serum estradiol, testosterone and progesterone levels in middle-aged male patients in the early phase of acute myocardial infarction.

\section{Materials and Methods}

The normal group and stress group (Group 3) were not given medication. The medications received by the myocardial infarction and unstable angina patients (nitrate or propranolol and rarely nifedipine, morphine and lidocaine infusion) are listed with hormone levels in Tables I and II. There were no differences between groups in age range, height and weight. Patients with diseases that affect hormone levels (eg, liver or kidney disease) were excluded from the study.

Group 1: Patients with myocardial infarction (acute phase). There were 13 patients in this group ranging from 30 to 56 years of age (average of 47.9 years). The diagnosis of acute myocardial infarction was based on the case history, electrocardiographic findings and serum creatine phosphokinase (CPK) levels. There was a 15 min to 3 hour interval between the occurrence

Levels in Acute Myocardial Infarction (Group $1 / \mathrm{MI}$ )

\begin{tabular}{|c|c|c|c|c|c|c|}
\hline \multicolumn{2}{|c|}{ Testosterone (ng/ml) } & \multirow{2}{*}{ Mean } & \multicolumn{3}{|c|}{ Progesterone (ng/ml) } & \multirow{2}{*}{ Mean } \\
\hline Day 2 & Day 3 & & Day 1 & Day 2 & Day 3 & \\
\hline 2.9 & 4.0 & 3.06 & 3.8 & 0.7 & 0.38 & 1.62 \\
\hline 5.6 & 7.0 & 4.86 & 1.8 & 0.34 & 0.38 & 0.84 \\
\hline 5.2 & 2.4 & 4.3 & 0.3 & 0.8 & 1.7 & 0.93 \\
\hline 4.1 & 5.6 & 4.83 & 0.32 & 0.57 & 0.52 & 0.47 \\
\hline 2.0 & 2.4 & 2.6 & 1.2 & 0.32 & 0.18 & 0.56 \\
\hline 2.7 & - & 3.35 & 3.0 & 1.5 & - & 2.25 \\
\hline- & - & 4.7 & 1.3 & 1.3 & 1.4 & 1.33 \\
\hline- & - & 6.9 & 0.6 & 0.9 & 0.34 & 0.61 \\
\hline- & - & 6.0 & 0.65 & - & - & 0.65 \\
\hline 5.3 & 7.0 & 6.03 & 0.4 & 0.5 & 0.6 & 0.5 \\
\hline 4.3 & 4.6 & 4.5 & 3.8 & 0.35 & 0.62 & 1.59 \\
\hline- & - & 2.9 & 5.25 & - & - & 0.19 \\
\hline 2.7 & 7.0 & 3.96 & 0.19 & - & - & 0.19 \\
\hline 3.86 & 5.00 & 4.46 & 1.74 & 0.728 & 0.657 & 1.29 \\
\hline 1.33 & 1.96 & 1.30 & 1.67 & 0.40 & 0.529 & 1.32 \\
\hline
\end{tabular}

* It is outlying statistically. 
Table II. Serum Estradiol, Testosterone and

\begin{tabular}{|c|c|c|c|c|c|c|}
\hline \multirow{2}{*}{$\begin{array}{c}\text { Patient } \\
\text { Number }\end{array}$} & \multirow{2}{*}{ Medication } & \multicolumn{3}{|c|}{ Estradiol $(\mathrm{pg} / \mathrm{ml})$} & \multirow{2}{*}{ Mean } & \multirow[b]{2}{*}{ Day 1} \\
\hline & & Day 1 & Day 2 & Day 3 & & \\
\hline 1 & prop & 53 & 45 & - & 49 & 6.8 \\
\hline 2 & prop + nife & 50 & 43 & 44 & 45.67 & 2.3 \\
\hline 3 & nitr & 49 & 40 & 44 & 44.3 & 11 \\
\hline 4 & prop + nitr & 48 & 210 & 48.5 & 102.17 & - \\
\hline 5 & prop & 340 & 210 & 60 & 213.33 & 5.2 \\
\hline 6 & nitr & 76 & 200 & - & 138 & 5.8 \\
\hline 7 & prop & 20 & 16 & 25 & 20.33 & 4.2 \\
\hline 8 & prop+nitr & 56 & 50 & 54 & 53.33 & 4.5 \\
\hline 9 & prop & 56 & 87 & 56 & 66.33 & 4.8 \\
\hline 10 & nitr & 48 & 68 & 75 & 63.66 & 4.2 \\
\hline 11 & nife & 65 & 57 & 83 & 68.33 & 4.5 \\
\hline 12 & prop+nitr & 70 & 45 & 49 & 54.66 & 3.6 \\
\hline 13 & prop & 68 & 55 & 96 & 73.0 & 3.1 \\
\hline Mean & & 76.9 & 88.9 & 57.7 & 76.31 & 5.0 \\
\hline $\mathrm{SD}$ & & 77.13 & 72.1 & 19.2 & 50.35 & 2.13 \\
\hline
\end{tabular}

of acute myocardial infarction and the examination of hormones. The medications taken by each patient are summarized in Table $\mathbf{I}$.

Group 2: Patients with unstable angina. There were 13 patients ranging from 29 to 52 years of age in this group (average 39.4 years). All these patients were hospitalized in the coronary care unit and suffered from myocardial ischemia, which was confirmed electrocardiographically. However, there was neither electrocardiographic nor enzymatic evidence of myocardial infarction. Patients with a history of myocardial infarction were excluded from this group. This group was examined to determine whether ischemia per se can affect serum estradiol, testosterone and progesterone levels. Coronary angiography was employed in 11 cases. In 10 of these, considerable stenoses were found angiographically. One patient had anterolateral and inferior ischemia and ST-T depression, but his coronary angiography was normal. Medications received by the patients are listed with data in Table II.

Group 3: Patients hospitalized in the intensive care unit, without a history of either coronary artery, liver or kidney diseases (stress group). This group consisted 13 patients ranging from 24 to 55 years of age (average 33.3 years). They were in the intensive care unit for various reasons; 6 with gastrointestinal bleeding, 3 with leg amputation, 4 with gunshot wounds. However, they had no previous history of coronary artery, liver or kidney disease. These patients were chosen in order to investigate the effects of the physical and emotional stress of severe illness on sex hormone levels. 
Progesterone Levels in Group 2 (Unstable Angina)

\begin{tabular}{cc|c|ccc|c}
\hline \multicolumn{2}{c|}{ Testosterone $(\mathrm{ng} / \mathrm{ml})$} & \multirow{2}{*}{ Mean } & \multicolumn{3}{|c|}{ Progesterone (ng/ml) } \\
\cline { 1 - 5 } Day 2 & Day 3 & & Day 1 & Day 2 & Day 3 & Mean \\
\hline 7.4 & 5 & 6.4 & 0.22 & 0.4 & 0.5 & 0.37 \\
1.6 & 2.9 & 2.27 & 0.24 & 0.16 & 0.53 & 0.31 \\
4.8 & 4.2 & 6.66 & 0.40 & 0.43 & 0.26 & 0.36 \\
- & - & - & 0.39 & 0.44 & 0.17 & 0.33 \\
4.0 & 3.7 & 4.3 & 0.9 & 2.6 & 0.57 & 1.36 \\
6.6 & 6.0 & 6.13 & 0.54 & 0.34 & 0.44 & 0.44 \\
4.5 & 3.4 & 4.03 & 0.29 & 0.38 & 0.27 & 0.31 \\
6.0 & 5.1 & 5.2 & 2.3 & 0.3 & 0.27 & 0.96 \\
4.5 & 3.4 & 4.23 & 0.60 & 0.56 & 0.40 & 0.52 \\
3.5 & 3.6 & 3.76 & 0.56 & 0.71 & 0.60 & 0.62 \\
4.0 & 3.8 & 4.1 & 0.53 & 0.60 & 0.38 & 0.50 \\
3.3 & 3.0 & 3.33 & 0.67 & 0.44 & 0.33 & 0.48 \\
4.7 & 4.2 & 4.0 & 0.75 & 0.79 & 0.62 & 0.72 \\
\hline 4.6 & 4.0 & 4.18 & 0.65 & 0.58 & 0.41 & 0.56 \\
1.49 & 0.89 & 1.78 & 0.52 & 0.44 & 0.14 & 0.30
\end{tabular}

Group 4: Control group (normal subjects). This group consisted of 15 normal subjects (age range: 25-54 years, average 39 years) who came to the cardiology (outpatient) clinic with non-specific complaints. Neither their case histories, ECG, CPK nor treadmill tests showed evidence of coronary artery disease or any other cardiac disorders.

Blood samples: Blood samples were taken from each patient in the first 3 groups on each of 3 consecutive days following hospitalization. Blood samples were taken from the normal group once.

Assay methods: Serum estradiol, testosterone and progesterone levels were determined by radioimmunoassay. EIR-RIA kits were used to determine estradiol levels; normal values were $14-45 \mathrm{pq} / \mathrm{ml}$ and the intraassay and interassay coefficients of variation were $9.7 \%$ and $9.2 \%$, respectively. For the determination of testosterone, Mallinckrodt Diagnostica $\mathrm{GmbH}$ kits were used; the intraassay and interassay coefficients of variation were $4.6 \%$ and $5.6 \%$, respectively.

To determine serum progesterone levels, Coat-A Count kits were provided by the Diagnostic Products Corporation. The normal values were $0.0-0.4 \mathrm{nq} / \mathrm{ml}$ and intraassay and interassay coefficients of variation were $7.5 \%$ and $6.6 \%$, respectively.

Other indices: The levels of total serum creatine phosphokinase were studied for 3 days immediately after hospitalization. These levels were determined using, Astra-8, Automated State/Routine analyzer. Normal 
AKSƯT, AKSƯT, KARAMEHMETOGLU, AND ORAM $\quad$ Jpn. Nearember $_{1986}^{J}$

Table III. Serum Estradiol, Testosterone and Progesterone Levels

\begin{tabular}{r|ccc|c|c}
\hline \multirow{2}{*}{ Patient } & \multicolumn{3}{|c|}{ Estradiol $(\mathrm{pg} / \mathrm{ml})$} & Mean & Day 1 \\
\cline { 2 - 5 } & Day 1 & Day 2 & Day 3 & & \\
\hline 1 & 16.5 & 18 & 45 & 26.5 & 5.8 \\
3 & 48 & 32 & 62 & 47.33 & 4.3 \\
4 & 50 & 57 & 40 & 49 & 5.8 \\
5 & 27 & - & - & 27 & 7.4 \\
6 & 40 & 38 & 43 & 40.33 & 4.6 \\
7 & 17 & 21 & - & 19 & 4.1 \\
8 & 17 & 27 & - & 22 & 6.4 \\
9 & 50 & 40 & 45 & 45 & 7.0 \\
10 & 36 & 31 & 27 & 31.33 & 6.8 \\
11 & 34 & 27.7 & 33 & 31.56 & 7.2 \\
12 & 32 & 31.3 & 22 & 28.43 & 7.5 \\
13 & 28.7 & 35 & 19 & 27.56 & 5.9 \\
\hline Mean & 35.5 & 41 & - & 38.25 & 6.0 \\
SD & 33.0 & 32.6 & 37.8 & 33.33 & 6.10 \\
& 11.4 & 10.3 & 13.4 & 9.73 & 1.10 \\
\hline
\end{tabular}

Table IV. Scrum Estradiol, Testosteronc and Progesterone Levels in Group 4 (Control)

\begin{tabular}{c|c|c|c}
\hline Control Number & Estradiol $(\mathrm{pg} / \mathrm{ml})$ & Testosterone $(\mathrm{ng} / \mathrm{ml})$ & Progesterone $(\mathrm{ng} / \mathrm{ml})$ \\
\hline 1 & 24 & 6.0 & 0.9 \\
2 & 32 & 6.8 & 0.4 \\
3 & 47 & 7.8 & 0.5 \\
4 & 23 & 7.0 & 0.14 \\
5 & 34 & 6.6 & 0.3 \\
6 & 30 & 5.0 & 0.2 \\
7 & 33 & 7.4 & 0.19 \\
8 & 26 & 5.6 & 0.74 \\
9 & 26 & 7.8 & 0.15 \\
10 & 43 & 6.5 & 0.27 \\
11 & 30 & 6.6 & 0.45 \\
12 & 32 & 6.8 & 0.35 \\
13 & 33 & 6.9 & 0.38 \\
14 & 36 & 7.4 & 0.47 \\
15 & 28 & 5.8 & 0.50 \\
\hline Mean & 31.8 & 6.67 & 0.4 \\
SD & 6.37 & 0.78 & 0.21 \\
& & & \\
\hline
\end{tabular}

values were 22-269 IU/L.

Statistical analyses: Differences among groups were tested by the analysis of variance (ANOVA), in addition, Student's t-test was performed to compare 
in Group 3 (Intensive Care Unit, No Coronary Heart Disease)

\begin{tabular}{cc|c|ccc|c}
\hline \multirow{2}{*}{ Testosterone (ng/ml) } & \multirow{2}{*}{ Mean } & \multicolumn{3}{|c|}{ Progesterone (ng/mi) } & \multirow{2}{*}{ Mean } \\
\cline { 1 - 6 } Day 2 & Day 3 & & Day 1 & Day 2 & Day 3 & \\
\hline 6.0 & 6.8 & 6.2 & 0.13 & 0.16 & 0.23 & 0.173 \\
4.2 & 3.8 & 4.1 & 0.78 & 0.36 & 0.18 & 0.44 \\
4.1 & 7.5 & 5.8 & 0.36 & 0.50 & 0.38 & 0.41 \\
- & - & 7.4 & 0.20 & - & - & 0.20 \\
4.9 & 6.2 & 5.23 & 0.36 & 0.36 & 0.23 & 0.31 \\
- & - & 4.1 & 0.42 & - & - & 0.42 \\
4.4 & 5.4 & 5.4 & 0.52 & 0.34 & - & 0.43 \\
6.0 & 6.0 & 6.33 & 0.36 & 0.80 & 0.6 & 0.59 \\
5.8 & 6.3 & 6.3 & 0.20 & 0.33 & 0.41 & 0.31 \\
6.3 & 6.7 & 6.75 & 0.29 & 0.36 & 0.52 & 0.39 \\
6.8 & 7.4 & 7.23 & - & 0.42 & 0.38 & 0.4 \\
7.2 & 5.9 & 6.33 & 0.32 & 0.44 & - & 0.38 \\
6.1 & 6.0 & 6.03 & 0.45 & 0.40 & 0.37 & 0.41 \\
\hline 5.6 & 6.20 & 5.93 & 0.36 & 0.41 & 0.37 & 0.37 \\
1.0 & 0.97 & 1.02 & 0.16 & 0.15 & 0.13 & 0.10
\end{tabular}

group means and determine the source of significance. Student's t-test was performed by comparing 3 days mean estradiol and testosterone values.

\section{Results}

The levels of serum estradiol, testosterone and progesterone in each case are shown in Tables I-IV.

Estradiol results: Differences among estradiol values of Control, Group 1, Group 2 and Group 3 were tested by ANOVA. The differences among the groups are statistically significant $(F=8.09 ; p<0.05)$. Patient 7 in Group 1 was not evaluated. The sources of the statistically significant differences were compared by Student's t-test. The results are presented in Table V and Fig. 1. No difference was found between the stress and normal groups or between the acute myocardial infarction and unstable angina groups. It was interesting that some serum estradiol values in acute myocardial infarction and unstable angina were as high as 340,310 and $275 \mathrm{pg} / \mathrm{ml}$. In our lab, the normal value is $10-35 \mathrm{pg} / \mathrm{ml}$.

Testosterone results: Differences among testosterone values of Control, Group 1, Group 2 and Group 3 were tested by ANOVA. The differences among groups are statistically significant $(F=12.158 ; \mathrm{p}<0.05)$. The sources of the statistically significant differences were compared using the Student's t-test. The results are presented in Table VI. 
Table V. Comparison of Means of Estradiol Values in Groups 1 to 4

\begin{tabular}{l|cccccc}
\hline Lstradiol & $\tilde{x}$ & SD & SE & n & $t$ & P \\
\hline Control & 31.8 & 6.59 & 1.7 & 15 & 3.67 & $<0.05$ \\
Group 1 & 48.44 & 14.53 & 4.2 & 12 & & \\
\hline Control & 31.8 & 6.59 & 1.7 & 15 & 3.164 & $<0.05$ \\
Group 2 & 76.31 & 50.35 & 13.96 & 13 & & \\
\hline Control & 31.8 & 6.59 & 1.7 & 15 & 0.48 & $>0.05$ \\
Group 3 & 33.33 & 9.73 & 2.7 & 13 & & \\
\hline Group 1 & 48.44 & 14.53 & 4.2 & 12 & 1.19 & $>0.05$ \\
Group 2 & 76.31 & 50.35 & 13.96 & 13 & & $<0.05$ \\
\hline Group 1 & 48.44 & 14.53 & 4.2 & 12 & 3.02 & $<0.05$ \\
Group 3 & 33.33 & 9.73 & 2.7 & 13 & & \\
\hline Group 2 & 76.31 & 50.35 & 13.96 & 13 & 3.021 & \\
Group 3 & 33.33 & 9.73 & 2.7 & 13 & &
\end{tabular}

SERUM ESTRADIOL

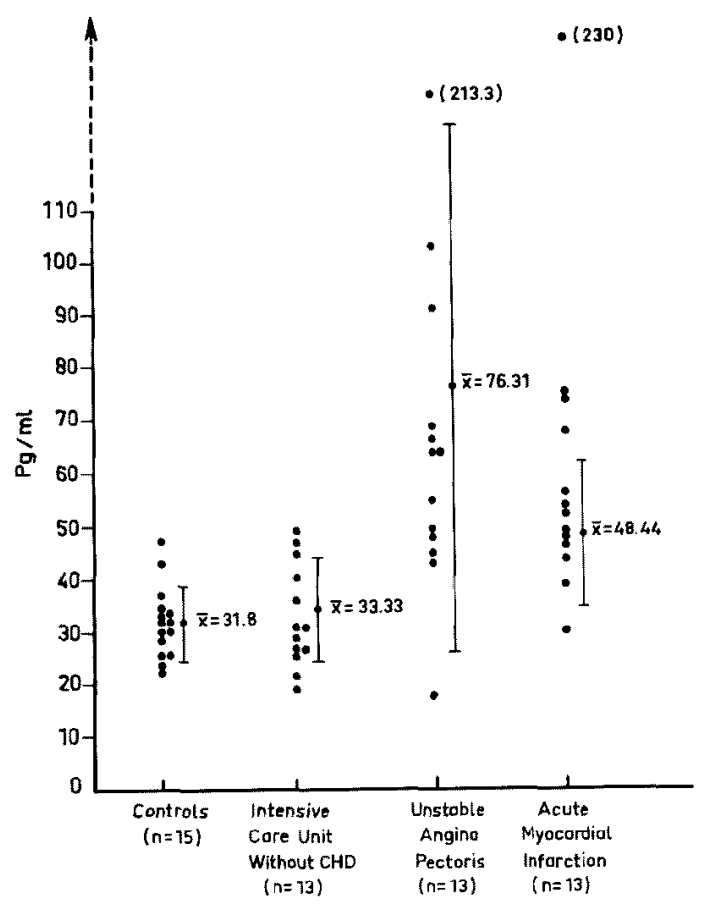

Fig. 1. Distribution of serum estradiol levels. 
Table VI. Comparison of Means of Testosterone Values in Groups 1 to 4

\begin{tabular}{l|llllll}
\hline Testosterone & $\overline{\mathbf{x}}$ & $\mathrm{SD}$ & $\mathrm{SE}$ & $\mathrm{n}$ & $\mathrm{t}$ & $\mathrm{p}$ \\
\hline Control & 6.67 & 0.801 & 0.21 & 15 & 5.285 & $<0.05$ \\
Group 1 & 4.461 & 1.307 & 0.36 & 13 & & \\
\hline Control & 6.67 & 0.801 & 0.21 & 15 & \multirow{2}{*}{4.637} & $<0.05$ \\
Group 2 & 4.185 & 1.78 & 0.49 & 13 & & \\
\hline Control & 6.67 & 0.801 & 0.21 & 15 & 2.081 & $>0.05$ \\
Group 3 & 5.937 & 1.021 & 0.28 & 13 & & \\
\hline Group 1 & 4.461 & 1.307 & 0.36 & 13 & 0.45 & $>0.05$ \\
Group 2 & 4.185 & 1.78 & 0.49 & 13 & & $<0.05$ \\
\hline Group 1 & 4.461 & 1.307 & 0.36 & 13 & 3.208 & $<0.05$ \\
Group 3 & 5.937 & 1.021 & 0.28 & 13 & &
\end{tabular}

SERUM TESTOSTERONE

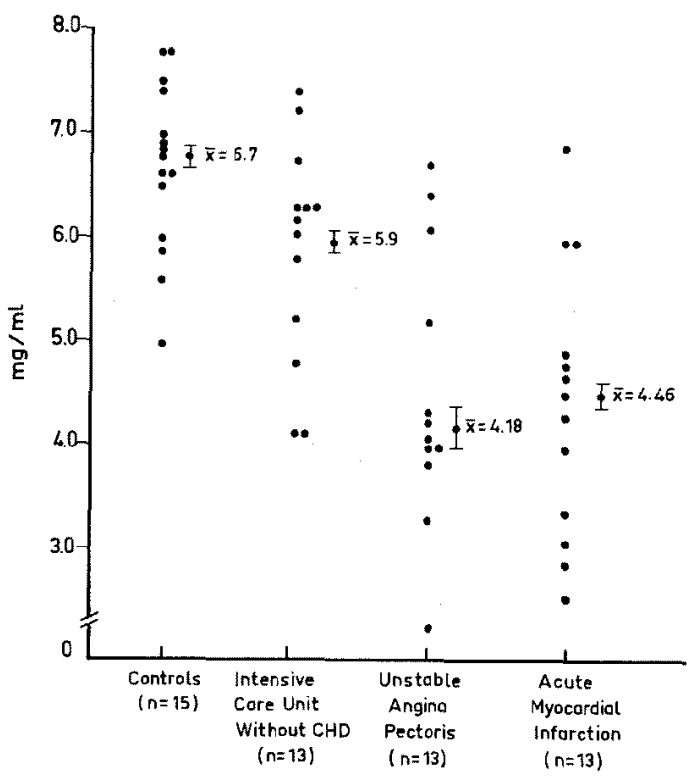

Fig. 2. Distribution of serum testosterone levels.

While the average serum testosterone levels were $6.7 \pm 0.80 \mathrm{ng} / \mathrm{ml}$ in the normal group, they were $4.46 \pm 1.30 \mathrm{ng} / \mathrm{ml}$ in the acute phase myocardial infarction group and $4.185 \pm 1.78 \mathrm{ng} / \mathrm{ml}$ in the unstable angina group. The levels of serum testosterone in the acute phase of myocardial infarction and 
unstable angina groups were significantly lower than the normal group (Fig. 2).

Progesterone results: The levels of serum progesterone in the acute phase of myocardial infarction were considerably higher than in the normal group. Values in the unstable angina group did not differ significantly from controls (Table VII).

Estradiol/Testosterone ratio $(E / T)$ : Differences among $\mathrm{E} / \mathrm{T}$ values of Control, Group 1, Group 2 and Group 3 were tested by ANOVA. The differences among the groups were statistically significant $(F=10.53 ; \mathrm{p}<0.05)$.

Table VII. Comparison of Means of Progesterone Values in Groups 1 to 4

\begin{tabular}{|c|c|c|c|c|c|c|}
\hline Progesterone & $\overline{\mathrm{x}}$ & $\mathrm{SD}$ & $S E$ & $\mathrm{n}$ & $\mathrm{t}$ & $\mathrm{p}$ \\
\hline Control & 0.4 & 0.21 & 0,06 & 15 & \multirow{2}{*}{2.41} & \multirow{2}{*}{$<0.05$} \\
\hline Group I & 1.29 & 1.32 & 0.37 & 13 & & \\
\hline Control & 0.4 & 0.21 & 0.06 & 15 & \multirow{2}{*}{1.64} & \multirow{2}{*}{$>0.05$} \\
\hline Group 2 & 0.56 & 0.30 & 0.08 & 13 & & \\
\hline Control & 0.4 & 0.21 & 0.06 & 15 & \multirow{2}{*}{0.34} & \multirow{2}{*}{$>0.05$} \\
\hline Group 3 & 0.375 & 0.10 & 0.03 & 13 & & \\
\hline Group 1 & 1.29 & 1.32 & 0.37 & 13 & \multirow{2}{*}{1.94} & \multirow{2}{*}{$>0.05$} \\
\hline Group 2 & 0.56 & 0.30 & 0.08 & 13 & & \\
\hline Group 1 & 1.29 & 1.32 & 0.37 & 13 & \multirow{2}{*}{2.48} & \multirow{2}{*}{$<0.05$} \\
\hline Group 3 & 0.375 & 0.10 & 0.03 & 13 & & \\
\hline Group 2 & 0.56 & 0.30 & 0.08 & 13 & \multirow{2}{*}{2.08} & \multirow{2}{*}{$<0.05$} \\
\hline Group 3 & 0.375 & 0.10 & 0.03 & 13 & & \\
\hline
\end{tabular}

Table VIII. Comparison of E/T Values in Groups 1 to 4

\begin{tabular}{l|cccccc}
\hline E/T & $\bar{x}$ & SD & SE & n & $t$ & p \\
\hline Control & 4.79 & 0.913 & 0.24 & 15 & 4.457 & $<0.05$ \\
Group 1 & 12.07 & 5.598 & 1.62 & 12 & & \\
\hline Gontrol & 4.79 & 0.913 & 0.24 & 15 & 3.615 & $<0.05$ \\
Group 2 & 16.98 & 11.65 & 3.36 & 12 & & \\
\hline Control & 4.79 & 0.913 & 0.24 & 15 & 1.507 & $>0.05$ \\
Group 3 & 5.822 & 2.318 & 0.64 & 13 & & $>0.05$ \\
\hline Group 1 & 12.07 & 5.598 & 1.62 & 12 & 1.316 & $<0.05$ \\
Group 2 & 16.98 & 11.65 & 3.36 & 12 & & \\
\hline Group 1 & 12.07 & 5.598 & 1.62 & 12 & 3.59 & $<0.05$ \\
Group 3 & 5.822 & 2.318 & 0.64 & 13 & & \\
\hline Group 2 & 16.98 & 11.65 & 3.36 & 12 & 3.25 &
\end{tabular}


This ratio was higher in the acute phase of myocardial infarction and unstable angina than in the normal group. However, no difference was found between the stress and normal groups (Table VIII).

\section{Discussion}

This study reveals that although the levels of serum estradiol rise significantly in coronary heart disease, the same values are normal in patients hospitalized for various acute illnesses. Similar results were achieved by various other researchers.3)-5),20) In this study, we did not investigate the levels of serum estrone because a previous study has shown that the level of estrone increases due to stress and is not specific to coronary heart diseases. ${ }^{1,4)-201}$ However, other investigators have concluded that the levels of serum estradiol increase only in coronary heart diseases and are not related to stress. ${ }^{20)}$ We did not investigate the effects of nitrate, propranolol or nifedipine drugs on the estrogen levels in normal subjects because it has been shown previously ${ }^{20}$ ) that no relationship exists between such drugs and estrogen levels. However, a possible contribution of these drugs to estrogen levels in patient Groups 1 and 2 cannot be excluded.

Estradiol is 3 times as biologically active as estrone and estrogen levels in coronary heart disease may be associated with increased adrenergic activity. The role of adrenergic activity in various cardiac diseases has been clearly defined, ${ }^{21)}$ and several actions of estrogens can increase adrenergic activity. For example, estradiol can increase adrenergic neurotransmitter synthesis, ${ }^{221,23)}$ inhibit the enzymatic degradation of adrenergic neurotransmitters ${ }^{24-26)}$ and potentiate the synaptic activity of the adrenergic neurotransmitters. ${ }^{27}$ ) In clinical studies estrogen also causes electroencephalographic changes similar to norepinephrine and amphetamine. ${ }^{28)}$ Thus, they may act as an adrenergic stimulant.

Since the demand for myocardial oxygen increases in occlusive coronary heart diseases as a result of adrenergic stimulation, an increase in the myocardial infarction size may be expected. Therefore, a rise in estradiol in coronary heart diseases may contribute to ventricular fibrillation, sudden cardiac death or massive myocardial infarction. Furthermore, heightened adrenergic stimulation secondary to a rise in estradiol levels has the potential to increase the demand for myocardial oxygen, resulting in pain due to myocardial ischemia. Although it has been difficult to determine whether estradiol levels rise in pre-acute myocardial infarction, our data confirm the finding ${ }^{20)}$ that the level of estradiol is high immediately after acute myocardial infarction and in unstable angina. The major source of estradiol in men 
consists of the aromatization of testosterone in muscle and adipose tissues. To a lesser degree, it is synthesized from estrone and by direct secretion from the testes. Estradiol is not produced in response to stress. ${ }^{29), 301}$ Therefore, the rise in the level of serum estradiol in coronary heart diseases cannot be related to stress. Finally, although estradiol increases due to obesity have been reported, our patients were not obese.

This study has also examined levels of serum testosterone ${ }^{31)}$ and progesterone as potential risk factors in coronary heart diseases. We have found that the levels of serum testosterone in the acute phase of myocardial infarction and unstable angina are significantly lower than in the normal group.

This confirms previous work by Poggi et al, ${ }^{19)}$ but it is different from other studies ${ }^{16), 31)}$ which detected no changes in serum testosterone in similar patients. A fall in the levels of testosterone may be due to the age of the patients, since older patients have lower testosterone levels and a higher risk of heart disease. ${ }^{32)}$ However, this can be excluded as an explanation in our study because the patients were middle-aged men.

\section{REFERENCES}

1. Phillips GB: Evidence for hyperestrogenaemia as a risk factor for myocardial infarction in men. Lancet II : 14, 1976

2. Phillips GB: Relationship between serum sex hormones and glucose, insulin, and lipid abnormalities in men with myocardial infarction. Proc Natl Acad Sci USA 74: 1729, 1977

3. Phillips GB: Sex hormones, risk factors and cardiovascular disease. Am J Med 65: 7, 1978

4. Entrican JH, Beach C, Carroll D, Kenmure ACF, Klopper A, Mackie M, Douglas AS: Raised plasma estradiol and estrone levels in young survivors of myocardial infarction. Lancet II: 487,1978

5. Hauss WH, Hulsing GJ, Wagner H, Rolfs HC, Bockel K, Hrubesch M: Über erhöhte 17- $\beta$ oestradiolspiegel im Blutbei patient mit arteriosclerose. Klin Wsch 51: 824, 1973

6. Coronary Drug Project: Initials findings leading to modifications of its research protocol. JAMA 214: 1303, 1970

7. Coronary Drug Project: Findings leading to discontinuation of the $2.5 \mathrm{mg} /$ day estrogen group. JAMA 226: 652, 1973

8. Veterans Administration Cooperative Urological Research Group: Treatment and survival of patients with cancer of the prostate. Surg Gynecol Obstet 124: 1011, 1967

9. James TN, Post HW, Smith FJ: Myocardial infarction in women. Ann Int Med 43: 153, 1955

10. Bengtsson C: Ischaemic heart disease in women. Acta Med Scand 549 (suppl): I-128, 1973

11. Kannel WB, Hjortland MC, McNamara PM, Gordan T: Menopause and risk of cardiovascular disease. Ann Int Med 85: 447, 1976

12. Editorial: Coronary heart disease and the menopause. Br Med J 1: 862, 1977

13. Mann JI, Inman WHW: Oral contraceptives and death from myocardial infarction. $\mathrm{Br}$ Med J 2: 245, 1975

14. Dalen JE, Hickler RB: Oral contraceptives and cardiovascular disease. Am Heart J 101: 626,1981 
15. Mann JI, Vessey MP, Thorogood M, Doll R: Myocardial infarction in young women with special reference to oral contraceptive practice. Br Med J 2: 241, 1975

16. Phillips GB, Gastelli WP, Abbott RD, McNamara PM: Association of hyperestrogenemia and coronary heart disease in men in the Framingham cohort. Am J Med 74: 863, 1983

17. US Department of Health, Education and Welfarc: National Heart and Lung Institute Workshop on Hormones and Arteriosclerosis, Hunt Valley Inn Cockeysville, Maryland, March 1972

18. Heller RF, Jacobs HS, Vermeulen A, Deslypere JP: Androgens, oestrogens and coronary heart disease. $\mathrm{Br}$ Med J 282: 438, 1981

19. Poggi UL, Arquelles AE, Rosner J, de Laborde NP, Cassini JH, Volmer MC: Plasma testosterone and serum lipids in male survivors of myocardial infarction. J Steroid Biochem 7: 229,1976

20. Klaiber EL, Broverman DM, Haffajee CI, Hochman JS, Sacks GM, Dalen JE: Serum estrogen levels in men with acute myocardial infarction. Am J Med 73: 872, 1982

21. Kattus A, Ross G, Hall VE: Cardiovascular Beta Adrenergic Responses, University of California Press, Berkeley, California, 1970

22. Greengrass PM, Tonge SR: The accumulation of noradrenaline and 5-hydroxytryptamine in three regions of mouse brain after tetrabenazine and iproniazid. Effects of ethinyloestradiol and progesterone. Psychopharmacologia (Berlin) 39: 187, 1974

23. Kendal DA, Narayana K: Effects of oestradiol-17 beta on monamine concentrations in the hypothalamus of anestrous ewe. J Physiol 282: 44, 1978

24. Kobayashi $\mathrm{T}$, Kato J, Minaguchi $\mathrm{H}$ : Cholinergic and adrenergic mechanisms in the female rat hypothalamus with special reference to feedback of ovarian steroid dynamics. Academic Press, New York, p 305-307, 1966

25. Luine VN, Khychevskaya RI, McEwen BS: Effect of gonadal steroids on activities of monoamine oxidase and choline acetylase in rat brain. Brain Press 86: 293, 1975

26. Ball P, Knuppen $\mathrm{R}, \mathrm{Haupt} \mathrm{M}$, Breuer $\mathrm{H}$ : Interactions between estrogens and catecholamines III. Studies on the methylation of catechol estrogens, catecholamines and other catechols by the catechol-o-methyltransferase of human liver. J Clin Endocrinol Metab 34: 736, 1972

27. Janowsky DS, Daris JM: Progesterone-estrogen effects on uptake and release of norepinephrine by synaptosomes. Life Sci 9: 525, 1970

28. Klaiber EL, Broverman DM, Vogel W, Kabayashi Y, Moriarty D: Effects of estrogen therapy on plasma. MAO activity and EEG driving responses of depressed women. Am J Psychiatry 128: 1492, 1972

29. Pratt JH, Longcope C: Effect of adrenocorticotrophic hormone on production rates and metabolic clearance rates of testosterone and estradiol. J Clin Endocrinol Metab 47: 307, 1978

30. Wang C, Chan V, Tse TF, Yeung RT: Effect of surgical stress on pituitary-testicular function. Clin Endocrinol 9: 255, 1978

31. Heller RF, Jacobs HS: Coronary heart disease in relation to age, sex and the menopause. Br Med J 1: 472,1978

32. Gutai J, La Porte R, Kuller L, Dia W, Falvo-Cerard L, Caggiula A: Plasma testostcrone, high density lipoprotein cholesterol and other lipoprotein fractions. Am J Cardiol 48: 897, 1981 